\title{
A BRIEF HISTORY OF ANAESTHESIA AND SURGERY OF THE HEART AND GREAT VESSELS*
}

\author{
KENNETH K. KEOWN
}

HISTORY is replete with prejudice, pathos and superstition. The history of cardiac and great vessel surgery and anaesthesia to sustain the surgical effort is no exception.

The early history of anaesthesia for operations on the heart is that of anaesthesia itself. The evolution of heart surgery per se was slow. Experimental work had started in 1882 . Block successfully closed heart wounds in rabbits and strongly advocated its use in man. Billroth nontheless continued a steadfast opposition to any cardiac surgical interference and in 1883 wrote: "A surgeon who would attempt such an operation (cardiac surgery) should lose the respect of his colleagues."

The demonstration by DeVecchio of a successfully sutured dog heart before the 11th International Medical Conference in Rome in 1894 confirmed the previous work of Block and aroused great interest. However, these demonstrations were still unconvincing to Padget who in 1896 wrote, "Surgery of the heart has probably reached the limits set by nature to all surgery; no new method and no new discovery can overcome the natural difficulties that attend a wound of the heart. It is true that heart surgery has been vaguely proposed as a possible procedure and has been done on animals, but I cannot find that it has been attempted in practice."

The desire to control blood loss during the repair of cardiac wounds prompted Sauerbruch to clamp off the base of the heart in order to work in a bloodless field. He showed that it was possible to clamp the cardiac pedicle for approximately one minute with recovery of the animal. He also found that caval occlusion alone permitted a relative dry field and at the same time extended the period of permissible circulatory exclusion to approximately three minutes.

Sir Lauder Brunton suggested in 1902 that the

Kenneth K. Keown, M.D., Department of Anesthesiology, W-350 Medical Center, University of Missouri-Columbia, Columbia, Missouri $\mathbf{6 5 2 1 2}$ U.S.A

*Presented in a Panel Discussion of Cardiac Anaesthesia and Surgery at the Annual Meeting, Canadian Anaesthetists' Society, Halifax, N.S., June 1981.

Can. Anaesth. Soc. J., vol. 29, no. 4, July 1982 results that had been obtained by surgical treatment of wounds of the heart emboldens one to hope that before very long similar good results may be obtained in cases of mitral stenosis. This communication aroused a rash of both condemnation and support. The Lancet attacked his proposal editorially in the next issue. The significance of Brunton's proposal was quickly grasped and precipitated a large volume of experimental cardiac operations in the succeeding years. In 1906 MacCallum demonstrated the physiological effects which result from experimentally produced mitral stenosis and mitral insufficiency. Trendelenburg in 1908 contributed to the development of cardiac surgery by his report of clinical attempts to remove massive emboli from the pulmonary artery by direct surgical attack. However, it was not until 1924 that Kirschner was able to record the first successful case of pulmonary embolectomy.

Tuffier in 1913 was the first to attempt a corrective operation on the heart in a patient, who had severe aortic stenosis. The procedure was successful and the patient lived for several more years. Rhythmic inflation and deflation of the lungs using a tracheal catheter was employed in this case.

Doyen in 1913 deliberately attempted to open a stenotic pulmonary valve by inserting a cutting edged instrument into the right ventricle and out the pulmonary artery. These two interventions in the same year on man opened the way to serious attempts at cardiac surgery.

In the United States Cutler, Levine and Beck began to investigate the surgical approach to mitral stenosis in 1920 and in 1923 operated on their first patient.

In 1925 Souttar inserted his finger into the mitral valve of a patient to relieve the stenosis by dilating and splitting the commissure digitally. This patient succumbed five years later from a cerebral embolus.

In 1935 interest in the surgical treatment of coronary artery disease was stimulated by Claude Beck when he published a report on his attempts to revascularize the myocardium. 325 
attack the congenital defect of patent ductus arteriosus surgically. Streider's patient died of respiratory insufficiency which was attributed to gastric dilatation.

As a result of the experience of World War II, anaesthetic and surgical techniques and practices have made major advances. Dwight Harkin reported his success in the removal of foreign bodies from the heart and great vessels of soldiers injured in combat.

Crafoord in Europe and Gross, Blaylock and Claggett in the United States were able to correct coarctation of the aorta. Each reported independently of the other with publications appearing in 1944,1945 and 1947.

The subject of cyanotic congenital heart disease was opened up in 1945 when Blaylock and Taussig published, "The Surgical Treatment of Malformations of the heart in Which There Is Pulmonary Stenosis Or Pulmonary Atresia". The following year Willis Potts of Chicago and his associates, amongst them the anaesthetist William O. McQuiston, reported their experiences with infants with congenital heart disease.

McQuiston clearly demonstrated the need to avoid marked increases in body temperature during operation in infants and children with cardiac and/or great vessels defects, and that as the core temperatures increased so did the mortality. He also speculated that a reduction of body temperature for such patients would be beneficial. McQuiston was the first to recognize the protective value of a reduced body temperature during anaesthesia.

Modern cardiac surgery dates from the first successful opening of a stenotic mitral valve achieved on June 10, 1948. The surgeon was Charles P. Bailey and I was the anaesthetist. The patient was alive and doing well twenty years later when, unfortunately, I lost contact with her. Thomas Durant, Chairman of the Department of Medicine at Temple University School of Medicine, named the procedure mitral commissurotomy.

Before the success of June 10,1948 , four patients with mitral stenosis, all of whom had class four mitral disease, had been anaesthetized and operated upon. The anaesthesia used endotracheal ether-oxygen, the belief then being that an ether-oxygen sequence was less depressing to the myocardium and hence the proper choice for intracardiac operations.

We learned very early the absolute need for the cardiac anaesthetist to be familiar with the symptoms, physical findings, laboratory data (when available) and the attitude of each patient considered as a candidate for operation. We also quickly grasped the need to be familiar with the medications each candidate was taking to avoid, when possible, duplications of drugs. Another of our early lessons was to inspect and remove all dnugs the patients had in their possession at the time they were admitted to hospital.

The most satisfactory method of selecting patients for heart surgery evolved to be a joint conference of the surgeon, cardiologists and the anaesthetists. The anaesthetist, to be effective, must utilize his or her training as a physician and make value judgments, lest he be relegated to the role of technician. Catheterization of the heart was not a routine study then. The Nobel Prize in Medicine was awarded later in 1956 to Dickinson W. Richards, Jr., and André F. Cournand of the United States and Werner Forssmann of Germany for doing the first cardiac catheterizations and proving its merit. Their original researches established the pressures within the right atrium, right ventricle and pulmonary artery in millimeters of mercury. The oxygen content of arterial and venous blood was not expressed in torr, but in volumes per cent. With the information available from cardiac catheterization the presence or absence of stenotic or regurgitant lesions or of septal defects could be determined.

Harold Griffith and G.E. Johnson of Montreal with the introduction of curare in clinical medicine in 1942 abolished the need for deep surgical anaesthesia to produce satisfactory conditions for tracheal intubation. Thereafter all early workers in heart anaesthesia used a curare-like drug to avoid the myocardial depression associated with deep levels of general anaesthesia.

Other advances followed rapidly. Sellors and Brock of England, working independently of each other, incised the stenotic opening of pulmonary values. Smithey and his associates in the United States were working on the problem of aortic stenosis before Smithey's untimely death in 1948 of that very disease.

In 1950 Bailey continued his previous success in valvular surgery by focusing his attention on the aortic valve. He opened the stenosis in the line of the fused commissures and called the operation aortic commissurotomy.

In the mid-fifties Bailey in Philadelphia; Swan in Denver; Shumaker in Indianapolis; Gross in Boston; Dodrill in Detroit; Gordon Murray in Toronto; Kirkland in Rochester, Minnesota; Hussefeldt, Crafoord and Bjork from Europe 
were reporting their experimental results with closure of atrial septal defects.

Lillihei with his co-workers Cohen, Warden and Varco reported in 1955 the first direct vision intracardiac correction of congenital anomalies by controlled cross circulation. Their experience opened a new frontier and indicated the need for heart-lung machines to allow total correction of intracardiac defects in a bloodless field. Lillihei and Kirklin were the first to make bloodless open cardiotomy possible with only minimal time constraints, in contradistinction to the limitations of time when hypothermia alone was being used for open cardiotomies.

In addition to the contributions made by the surgeons that pioneered heart and great vessel surgery, many in anaesthesia were making significant contributions. The forerunners from England were Wylie, Lucas, Sellick and Brown; Fairley, Evelyn and Sutton from Canada; Smith, Artusio, Virtue, Patrick, Moffitt, Pender, McQuiston, Buckley, Mendelsohn and Hale from the United States.

The principal changes that have occurred from 1948 to 1981 are criteria of patient selection, the monitoring equipment available, the acceptance by the cardiologist of the value of surgical intervention, the improved post-operative respiratory care, the use of cardiac pacemakers, the role of computers and the length of time available for open cardiotomy and bypass operations afforded by the mechanically and physiologically more acceptable heart-lung apparatus.

Dean Morrow proved first in the laboratory and then in the clinical areas that curare could overcome many of the untoward pharmacological effects of over-digitalization. He also found that halothane had the effect of reducing most of the toxic effects associated with digitalis overdosage.

The introduction of halothane in 1956 was particularly helpful as it could be vapourized in the heart-lung apparatus, which markedly facilitated the ability of the anaesthetist to provide a smooth transition to and from the pumpoxygenator.

There is no question that there was lack of appreciation in the 1948-1965 era of the importance of electrolyte balance, of the untoward cardiac effects of respiratory alkalosis, what could be achieved by the appropriate use of beta blockers, as well as a host of other advances of the past fifteen years.

Favolaro and Effler in 1967, as a direct result of Sones cine coronary arteriography techniques began the trend toward coronary artery bypass surgery using saphenous vein grafts.

This advancement changed the types of cardiac disease we were called upon to anaesthetize. Adults with various valvular lesions secondary to rheumatic fever and/or scarlet fever gave way to the saphenous vein bypass grafts for patients with coronary artery disease and myocardial ischaemia. As this shift in cardiac surgery took hold, the number of heart-lung machines throughout most of the English-speaking world increased rapidly. There is some doubt whether the profusion of cardiac teams is either indicated or reflects the best use of limited health care funds.

In summary, the success of surgery for heart disease is a direct result of ten factors:

1. Anaesthetic developments that allow thoracotomy to be accomplished successfully;

2. The development of chemotherapeutic agents that minimize or prevent postoperative infection;

3. The development of blood banks which allow blood and blood products to be stored and used as needed;

4. The ability of the cardiovascular surgeon to solve the mechanical problems of the various heart lesions;

5. The desire of the practitioners of medicine to aid their patients by referring them to cardiac centers;

6. The courage of patient, physician, surgeon and anaesthetist in attempting the unknown and entering upon uncharted courses;

7. Improved heart-lung machines that provide better tissue oxygenation and perfusion;

8. Pre-operative and post-operative respiratory care;

9. Improved anaesthetic agents; and

10. Monitoring equipment and improved pre-, peri- and post-anaesthetic evaluations.

No single factor has been all-important in the achievement of success in this field of medicine. It is truly the teamwork of the entire medical profession, nursing personnel and hospital staff that has afforded so many patients a new tenure on life.

\section{BIBLIOGRAPHY}

Liston, R. Lectures on the Operations and on Diseases and Accidents Requiring Operations, Philadelphia, Lea \& Blanchard, 1846.

Dioscordes, Libri Octo Grace and Latin, Page 219 Goupyl, Paris, 1549. 
Vesalius, A. De Humani Corporis Fabrica, Ist ed. Basel, 1543, p. 658 .

Hooke, R. Preserving Animals Alive by Blowing Air through their Lungs with Bellows, Phil. Trans. Royal Soc., 2: 539, 1667.

SNOw, J. On Chloroform and Other Anaesthetics, London, J. Churchill, 1858.

MACEWEN, W. Clinical Observations on the Introduction of Tracheal Tubes by the Mouth Instead of Performing Tracheotomy or Laryngotomy, Brit. Med. J. 2: 122, 163, 1880 .

Trendelenburg, F. Zur Operation der Emoblie der Lungenarterie, Deutsche med. Wchnsch, 34, 1172, 1908.

MAYDL, K. Wher dil Intubation des Larynx als Mitten Gegen das Einfliessen von Blut in dil Respirations Organe bie Operationen, Wein. Med. Wschr. 43 $57,102,1893$

EISENMENGER, V. Zur Tamponade des Larynx Nach. Prof. Maydl, Wein. Med. Wschs. 43: 199, 1893.

TUFFier, T. \& Hallion, C.R. Operation Intrathoraciques Avec Respiration Artificielle par Insufflation C.R. Soc. Biol. 48: 951, 1896.

Meltzer, S.J. \& AUER, J. Continuous Respiration Without Respiratory Movements, J. Exp. Medl, 1]: 622, 1909.

Jackson, C. The Techniques of Insertion of Intratracheal Insufflation Tubes, Surg. Gyne. Obstet. 17: 507,1913

MAGILL, I.W. Appliances and Preparation Forceps for Intratracheal Anaesthesia, Brit. Med. J. 2:670, 1920 .

Waters, R.M., Rovenstine, E.A. \& Guebel, A.E. Endotracheal Anesthesia and its Historical Development, Anesth. Analg., 12: 196, 1933.

ARTusto, J.F., JR. Anesthesia Management of the Rheumatic Cardiac for Mitral Valvulotomy. Bull. New York Read. Med., 29: 604, 1953.

Keown, K.K., Grove, D.D. \& RUTH, H.S. Anesthesia for Commissurotomy for Mitral Stenosis., J.A.M.A., 146: 446, 1951.

Carbriolawns, Diodorus Siculus cited by Ballance, Sir Charles A. The Bradshaw Lecture on the Surgery of the Heart, London, MacMillan and Co., 1920.

MoRGaGNI, J.B. The Seats and Causes of Diseases, Translated by B. Alexander, London, Miller \& Cadell, 1769.

RoMEro, Cited by Paget, S. The Surgery of the Chest, 479 p.p., New York, E.B. Treat 1897.

LARREY, D.J., Cited by Ballance, Sir Charles A. The Bradshaw Lecture on the Surgery of the Heart, London. MacMillan \& Co. 1920.

Blllroth, T., Die Chirurgie der Blutgefasse und. des Herzens, Berlin, A. Hirschwald 1913, P. 295.

BLOCK, M.H., Uber Wunden des Herzen und des Herzbentelf, Verhandle d. deutsch Gesellsch f., Chir. 11, 108, 1882.

DEVecchio, S. Sutura del Curore, Riforma. Med. 2, 38, 1895 .

Paget, S. The Surgery of the Chest, p. 479, New York, E.B. Treat, 1897

BeCKER, O. Ueber die Sichtbaren Erscheinungen der Blutbewegen in der Menschlichen Nitzhaut, Arch. F. Ophth $18,206,1872$.

KLEBS, E. Uber Operative Verletzungen der Herzklappen und deren Folgen, Prag. Med. Wchnschr, $1,29,1876$.
KRONECKER \& Schmey. Le Centre de Coordination des Mouvements du Ventricle du Coeur, Semacne, Med., Paris, June, 1804.

SAUERBRUCH, F. Die Verwenbarkeit des Unterdruckverfahrens in der Heizchirurgie, Verhandl. d. deutsch Gessellsch. F. Chir. 36, 245, 1907.

SaMways, D.W. Cardiac Peristalsis, Lancet 1,927, 1898

Brunton, L. Possibility of Treating Mitral Stenosis by Surgical Methods, Lancet 1, 352, 1902.

Editorial: Surgical Operation for Mitral Stenosis, Lancet 1, 461, 1902.

MaCCALLUM, W.G. On the Mechanical Effect of Experimental Mitral Stenosis and Insufficiency, Bull. Johns Hopkins Hosp., 17, 260, 1906.

KuRsChNER, M. Ein durch die Trendelen-burgsche Operation Geheilter Fall von Embolie der Art. Pulmonalis, Arch. f. Klin. Chir., 133, 312, 1924.

Jeger, E. Die Chinurgie der Blatgetasse und des Herzens, Berlin, Hirschwald, 1913.

Tuffier, T. Etat Actuel de la Chirurgie Intrathoracique, Tr. Internat. Med. Cong., London, 1913

DOYEN, E. Chirurgie des Malformations Congenitales ou Acquises du Coeur., Presse Med. 21, 860, 1913.

Cutler, E.C., Levine, S.A. \& Beck, C.S. Surgical Treatment for Mitral Stenosis, Arch. Surgery. 9, 689,1924

SouTTAR, H.S. Surgical Treatment of Mitral Stenosis, Brit. Med. J., 2, 603, 1925

BECK, C.S. Development of a New Blood Supply to the Heart by Operation, Ann. Surg. 102, 881, 1935

GiBBON, J.H. JR. Artificial Maintenance of Circulation During Experimental Occlusion of the Pulmonary Artery. Arch. Surg. 34: 1105, 1937.

Graybiel, A., Strieder, J.W. \& Boyer, N.A. Attempt to Obliterate Patent Ductus Arteriosus in Patient with Subacute Bacterial Endarteritis, Am. Heart J., 15, 621, 1938.

HARKEN, D.E. Foreign Bodies in, and in Relation to, the Thoracic Blood Vessels and Heart, Surg. Gynec. and Obst., 83, 117, 1946.

Crafoord, C. \& Nylin, G. Congenital Coarctation of the Aorta and Its Surgical Treatment, J. Thor. Surg., 14, 347, 1945.

Gross, R.E. \& HufNagel, C.A. Coarctation of the Aorta, New Eng. J. Med., 233, 287, 1945

Blalock, A. \& Park, E.A. Surgical Treatment of Experimental Coarctation of the Aorta Ann. Surg., $119,445,1944$.

Clagetr, O.T. Coarctation of the Aortas. Proc. Staff Meet., Mayo Clinic, 22, 131, 1947

Blalock, A. \& Taussig, H.B. The Surgical Treatment of Malformations of the Heart in Which There is Pulmonary Stenosis or Pulmonary Artesia, J.A.M.A., 128, 189, 1945.

PotTs, W.J., SMITh, S. \& Gibson, S. Anastomosis of the Aorta to a Pulmonary Artery, Certain Types in Congenital Heart Disease, J.A.M.A., 132, 627, 1946.

Favaloro, R.G. Saphenous Vein Autografts Replacement of Severe Segmental Coronary Artery Occlusion. Ann. Thorac Surgery, 5: 334, 1968.

ALLEN, D., ConN, A.W. \& JUNKIN, C.E. A Year of Paediatric Cardiovascular Anaesthesia. Canad. Anaesth. Soc. J, 6: 322-366, Oct. 1959. 
Bigelow, W.G., Callaghan, J.C. \& Hopps, J.H. General Hypothermia for Experimental Intracardiac Surgery. Ann. Surg. 32: 531, 1950.

Bigelow, W.G., \& Mustard, E. Some Physiologic Concepts of Hypothermia and their Application to Cardiac Surgery, J. Thorac. Surg. 28, 463, 1954

Brock, R. Pulmonary Valvulotomy for Relief of Congenital Pulmonary Stenosis, Brit. M.J. 1: $1121,1948$.

DAwson, B. Theye, R.A. \& Kirktin, J.W. Halothane in Open Cardiac Operations: A Technique for Use with Extracorporeal Circulation. Anesth. Anal. 39: 59-63, Jan. 1960

EFrLer, D.B. \& Groves, L.K. Complications Peculiar to Open Heart Surgery, Surgery, 45, 149-159, Jan. 1959

Hufnagel, C.A. Aortic Plastic Valvular Prostheses. Bull. Georgetown Univ. M. Ctr., 4: 129, 1951

MCQuiston, W.O. Anesthesia in Cardiac Surgery; Observations on 362 Cases. Arch. Surg. 61, 892, 1950

MofFIT, E.A. \& THEYE, R.A. Management of Anesthesia, Perfusion and Supportive Care During Open Intracardiac Operations and Extracorporeal Circulation. Brit. J. Anaesth. 31: 411, Sept. 1959.

Ridiey, R.W. \& PENDER, J.W. Anesthesia for Cardiovascular Operations. Canad. M.A.J. 71: 32, 1954

Swan, H. , Zeavin, I., Blount, S.G. Jr \& VirTue, R.W. Surgery by Direct Vision in the Open Heart During Hypothermia J.A.M.A., 153: 1081, 1953.

TAYLOR, C \& STOELTING, V.K. Halothane Anaesthe- sia for Paediatric Cardiac Surgery. Can. Anaesth. Soc. J. 8: 247, May, 1961.

McGoon, D.C., Moffit, E.A., Theye, R.A. \& KIRKLIN, J,W. Physiologic Studies during High Flow Normothermic Whole Body Perfusion, J. Thorac. Surg. 39: 275, March 1960.

HirchCock, P. \& Keown, K.K. The Management of Cardiac Arrhythmias During Cardiac Surgery. South. Med. J., 52: 702, 1959.

HitCHCOCK, P. \& KEOWN, K.K. Lidocaine in Control of Cardiac Arrhythmias. Fed. Proc. 17: 1490, 1958.

Bigelow, W.G., LINDSEY, W.K., HaRRISON, R.C. Gordon, R.A. \& GREENWOOD, W.F. Oxygen Transport and Utilization in Dogs at Low Temperature. Am. J. Physiol., 100: 125, 1950.

Starr, A. \& EDWARds, M.L. Mitral Replacement: Clinical Experience with a Ball Valve Prosthesis, Ann. Surg. 154: 726, 1981.

SonEs, F.M., JR. \& SHIREY, E.K. Cine Coronary Arteriography, Mod. Concepts Cardiovase. Dis., 31: 735, 1962.

MofFIT, E.A., The Mayo-Gibbon PumpOxygenator and Its Uses, In Keown, K.K. Anesthesia for Surgery of the Heart, Springfield, ILL. Charles C Thomas, 1963. p. 150

LITTLE, D.M. JR. \& SUTTON, G.C. Succinylcholine Nitrous Oxide Anaesthesia for Mitral Commissurotomy. Can. Anaesth. Soc. J., 2: 156, 1955.

KEOWN, K.K. Anesthesia for Surgery of the Heart, Springfield, Charles C. Thomas, 1963. 